\title{
Statyba
}

\section{DETERMINATION OF RELATIONSHIP $\sigma(\#)$ OVER THE YIELD STRESS OF CONCRETE REINFORCING STEELS}

\section{G. Marčiukaitis \& A. Šneideris MSc (Eng).}

To cite this article: G. Marčiukaitis \& A. Šneideris MSc (Eng). (1999) DETERMINATION OF RELATIONSHIP $\sigma(\#)$ OVER THE YIELD STRESS OF CONCRETE REINFORCING STEELS, Statyba, 5:4, 237-244, DOI: 10.1080/13921525.1999.10531470

To link to this article: https://doi.org/10.1080/13921525.1999.10531470

曲 Published online: 26 Jul 2012.

Submit your article to this journal

Џll Article views: 47 


\section{TEMPIAMOSIOS ARMATŪROS $\sigma(\varepsilon)$ PRIKLAUSOMYBĖS VIRŠ TAKUMO RIBOS NUSTATYMAS}

\section{G. Marčiukaitis, A. Šneideris}

\section{Ivadas}

Konstrukcinès statybinès medžiagos, tokios kaip betonas, armatūra ir pan., po apkrova deformuojasi skirtingai. Šis konstrukcijų deformavimasis vyksta skirtingai, sukeldamas ịvairios formos ir dydžio itempių būvį [1, 2]. Yra daug veiksnių, kurie lemia lenkiamuju gelžbetoninių elementu ịtempių-deformacijų būvị. Iki tam tikros ribos šis būvis kinta ir, esant linijiniam valkšnumui, jo kitimas stabilizuojasi. Pasikeitus sąlygoms jis gali keistis: itempiai-deformacijos betone ir armatūroje gali padidèti arba šiek tiek sumažèti. Didžiausią būvio pasikeitima, kai nepažeista konstrukcija, sukelia ivairių poveikių (apkrovı temperatūros ir pan.) pokyčiai.

Pastatus modernizuojant ir rekonstruojant, labai dažnai reikia įvertinti konstrukcijų būvi ir jas stiprinti.

Stiprinant konstrukcijas papildoma armatüra, turi būti nustatyta, kaip panaudojama jų tempiamojoje zonoje esanti armatūra ir likęs jos laikymo galios resursas. Skaičiavimais vertinant šią armatūrą bütina atsižvelgti i tai, kokią ittempių-deformacijų būvio stadiją ji jau yra pasiekusi.

Tačiau, nežinant faktiniu betono ir armatūros itempiu, negalima tiksliai izvertinti betono ir tempiamosios armatūros laikomosios galios resurso (likučio). Pridedant papildomos armatüros reikia žinoti, kokią apkrovos dalı̣ galès perimti esama armatūra ir ar ji nèra pasiekusi savo ribinès laikomosios galios.

Kaip parodyta 1 pav., esama ir papildomai po tam tikro laiko pridèta armatūra apkrovus deformuosis skirtingai. Pasikeičia gniuždomosios betono zonos būvis ir visas itempių-deformaciju būvis. Tarp skirtingose stadijose esančiu armatūrų vyksta ittempiu persiskirstymas. Visa tai svarbu ivertinti, nustatant stiprinamų konstrukcijų laikomają galią ir jụ deformacijas.

Norint ịvertinti šių itempių persiskirstymą kad geriau abi armatūros būtų panaudojamos, būtina žinoti ar- matūros itempių-deformacijų analitines išraiškas. Be to, visas $\sigma(\varepsilon)$ priklausomybes reikia žinoti, norint ivertinti konstrukcijų būvị visose stadijose, iskaitant ir suirima.

Projektavimo normose nurodyta, kad, kai lenkiamasis elementas stiprinamas po apkrova, didesne kaip $65 \%$ nuo skaičiuojamosios, elementų normalinių pjūvių laikomoji galia mažeja. Tačiau tokio mažèjimo pagristo pagrindimo nèra. Todèl būtina žinoti esamos ir stiprinant papildomai pridètos armatūrų itempius-deformacijas, ju tarpusavio persiskirstymą toliau eksploatuojant konstrukcija.

Yra pasiūlyta ivairių konstrukcijų stiprinimo ir skaičiavimo büdų $[3,4]$. Tačiau tokie skaičiavimai sudetingi ir jais neivertinamos stiprinamu konstrukciju medžiagu plastinès deformacijos.

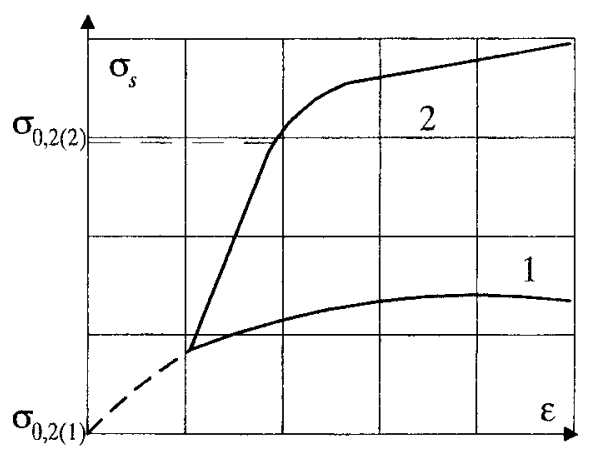

1 pav. Armatūros ịtempių-deformacijų diagrama: 1 - esančios elemente, 2 - papildomai pridetos

Fig 1. Stress-strain curves for the reinforcement: 1 - placed in the structure, 2 - added on structure as additional reinforcement

Konstrukcijas, sustiprintas iš anksto itemptomis templèmis arba papildoma neittemptaja armatūra, galima skaičiuoti ir iš stiprumo salygos, taikant formules paprastoms gelžbetoninėms konstrukcijoms skaičiuoti. Tačiau tai neleidžia ịvertinti armatūros ịtempių-deformaciju būvio virš takumo ribos. Nustatyta, kad stiprinimo metodui parinkti ir skaičiavimo tikslumui didelę reikšmę turi itempiai konstrukcijos armatūroje (ypač kritiniu atveju, 
kai jie viršija takumo ribą), papildomos armatūros panaudojimas ir ịrąžu persiskirstymas tarp šiu armatūrų. Tam būtina žinoti îtempių-deformacijų priklausomybes ịvairiose armatūros būvio stadijose.

\section{Armatũros $\sigma(\varepsilon)$ diagramų aprašymo analizè}

Gelžbetoninių konstrukcijų armatūra kinta kartu su betonu. Priklausomybè tarp itempių-deformacijų tempiamajai armatūrai, esančiai betone, būtu išreiškiama idealia diagrama, jei plyšiams atsiradus iš karto būtú pašalintas sukibimas tarp betono ir armatūros per visą ilgi tarp plyšių. Tačiau iš tikruju atsiradus plyšiams sukibimas tarp betono ir armatūros jei ir pašalinamas, tai tik nedideliuose ruožuose, esančiuose prie pat plyšio. Šių ruožu ilgis priklauso nuo armatūros paviršiaus kokybès, nuo armavimo procento, armatūros skersmens, kitų faktorių ir kai kuriais atvejais gali būti labai mažas. Todèl ideali itempiųdeformaciju diagrama tinka tik pjūviams su plyšiais. Tačiau praktiškai šios diagramos naudojamos taikant koeficientus, ivertinančius betono tarp plyšių itaką armatūros būviui.

Šiuo metu daugiausia rekomenduojamų $\sigma_{s}\left(\varepsilon_{s}\right)$ diagramų aprašymų, skirtų armatūrai, išreiškiama laipsniniais daugianariais arba tiesinèmis trupmeninemis funkcijomis.

Paprastai armatūrinių plienų $\sigma_{s}\left(\varepsilon_{s}\right)$ priklausomybès nèra analogiškos betono priklausomybèms, nes ju pagrindą sudaro visiškai skirtingos funkcijos. Tai griauna formuliu vienareikšmiškumą ir apsunkina gelžbetoninių elementu pjūvio itempių-deformacijų vertinimo matematinị modeli.

Yra pasiūlyta [5] analitinè stipriosios armatūros tempimo diagrama, susidedanti iš dviejų ruožų - pirmasis nuo 0 iki $\sigma_{0,02}$, antrasis nuo $\sigma_{0,02}$ iki $\sigma_{u}$. Antraji ruožą aprašant nepriklausomaisiais dydžiais imami $\sigma_{0,2}$; $\bar{m}_{s 4}=\sigma_{u} / \sigma_{0,2}$ ir $E_{s}$. Taikant logaritminę ir atvirkštinę funkcijas, antrojo ruožo aprašymui yra gauta tokia priklausomybe:

$$
\sigma_{s}=S-K \frac{\ln C_{1}\left(\varepsilon_{s}+L\right)}{C_{2}\left(\varepsilon_{s}+L\right)},
$$

$S$ ir $K$ - funkcijos, rodančios armatūros charakteristiku itaką itempių-deformacijų priklausomybei, $C_{1}, C_{2}$ ir $L$ rodo tų pačių charakteristikų ittaką armatūros deformacijoms.
Apdorojant eksperimentines kreives gauti koeficientai $S, K$ ir $L$, kuriu išraiškas istačius i (1) priklausomybę, gaunama tokia formulè:

$$
\sigma_{s}=S-K \frac{\ln 10\left(\varepsilon_{s} \cdot 10^{3}+L\right)}{\varepsilon_{s} \cdot 10^{3}+L}
$$

Priklausomybei $\sigma_{s}\left(\varepsilon_{s}\right)$ gauti buvo taikytos eksperimentinès stipriujų armatūrinių plienų tempimo diagramos (2 pav.). Artèjimo funkcija:

$$
\varepsilon_{s}=\frac{K_{0}}{A-\sigma_{0}}+D
$$

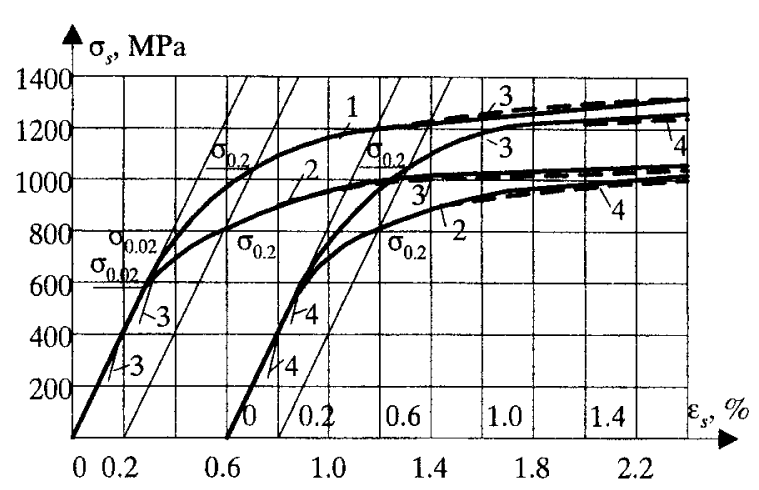

2 pav. $A_{T}$ VI ir $A_{T}$ V klasiu armatūru tempimo diagramos: 1 ir 2 - vidutinés statistinés diagramos; 3 - pagal (2) formulę; 4 pagal (4) formulę

Fig 2. Stress-strain curves for the reinforcement $A_{T}$ VI and $A_{T}$ $V$ class: 1 and 2 - average statistic curve; 3 - according to formula (2); 4 - according to formula (4)

Ivertinus galimus tamprumo modulio nukrypimus nuo vidutinių reikšmių, ši priklausomybè igauna tokią išraišką:

$$
\varepsilon_{s} \cdot 10^{3}=\frac{K_{0}}{A-\sigma_{0}}-D+\frac{\sigma_{s}\left(1,9 \cdot 10^{5}-E_{s}\right)}{1900 \cdot E_{s}},
$$

$A, D$ ir $K_{0}$ - koeficientai, kuriais ivertinamas armatūros klasès tipas.

Laikoma [6], kad tikslesnis itempių-deformaciju diagramos aprašymas yra toks:

$$
\varepsilon_{s}=\frac{\sigma_{s}}{E_{s}}+m\left(\frac{\sigma_{s}}{\sigma_{0,2}}-\eta\right)^{3}
$$

$m=\frac{0,002}{(1-\eta)^{3}}$, o santykiné tamprumo riba $\eta$ pateikiama funkcijomis $\sigma_{0,05}$ ir $\sigma_{0,2}: \eta=1-2,7 \frac{\sigma_{0,2}-\sigma_{0,05}}{\sigma_{0,2}}$. 
(5) lygties dešinès pusès antroje dalyje aprašomos tampriai plastinès deformacijos, t. y. deformacijos virš takumo ribos.

Gaunama tempimo po apkrova diagramos išraiška tampriai plastinems deformacijoms:

$$
\varepsilon_{s}=\left\{\begin{array}{l}
\frac{\sigma_{s}}{E_{s}}+m_{1}\left(\frac{\sigma_{s}}{E_{s}}-\eta_{1}\right)^{n_{1}}, \sigma_{y} \leq \sigma_{s} \leq \sigma_{0,2} \\
\frac{\sigma_{s}}{E_{s}}+m_{1}\left(\frac{\sigma_{s}}{E_{s}}-\eta_{1}\right)^{n_{1}}+m_{2}\left(\frac{\sigma_{s}}{E_{s}}-1\right)^{n_{2}}, \\
\frac{\sigma_{0,2} \leq \sigma_{s} \leq \sigma_{0,5}}{\sigma_{s}}+m_{1}\left(\frac{\sigma_{s}}{E_{s}}-\eta_{1}\right)^{n_{1}}+m_{2}\left(\frac{\sigma_{s}}{E_{s}}-1\right)^{n_{2}}+ \\
+m_{3}\left(\frac{\sigma_{s}}{E_{s}}-\eta_{3}\right)^{n_{3}}, \sigma_{0,5} \leq \sigma_{s} \leq \sigma_{u} .
\end{array}\right.
$$

Pateiktas variantas remiasi eksperimentiniu priklausomybių splainų interpoliavimu. Dažniausiai taikomi kubiniai splainai. [7] pateikta analitinès išraiškos aprašymo, jungiančio $\sigma_{s}$ ir $\varepsilon_{s}$, forma pakankamai tiksliai sutampa su eksperimentiniais viso diapazono (nuo 0 iki $\sigma_{s u}$ ) rezultatais.

Rengiant Euronormas buvo siūloma [8] aprašymui imti tokią bazinę unifikuotą betonui ir armatūrai $\sigma(\varepsilon)$ diagramų funkcija, gautą remiantis kreivaisiais splainais:

$$
v_{s}=\frac{k \eta_{s}-\eta_{s}^{2}}{1+(k-2) \eta_{s}}
$$

cia $\eta_{S}=\frac{\varepsilon_{S}-\varepsilon_{S 0}}{\varepsilon_{S R}-\varepsilon_{S 0}}, \nu_{S}=\frac{\sigma_{S}-\sigma_{S 0}}{\sigma_{S R}-\sigma_{S 0}}$,

indeksai 0 ir $R$ reiškia nagrinejjamo diagramos ruožo pradžią ir pabaigą.

Stipriujų plienų diagramos ( 3 pav. a) skaidomos $i$ tris ruožus: tiesini ir du kreivuosius, kurie aprašomi viena ir ta pačia priklausomybe (7), kuri gali transformuotis i skirtingas išraiškas.

3 pav. pavaizduotas splainas turi fiksuotus taškus 0 , $\mathrm{A}, \mathrm{B}, \mathrm{C}$ su koordinatemis 0,$0 ; \sigma_{e l}, \varepsilon_{e l} ; \sigma_{0,2}, \varepsilon_{0,2} ;$ $\sigma_{u}, \varepsilon_{u}$.

Irašant i formulę (7) reikšmes $\sigma_{S 0}, \varepsilon_{S 0}$ ir $\sigma_{S R}$, $\varepsilon_{S R}$, atitinkančias kiekvieno ruožo galus [9] kiekvienam ruožui gaunamos atitinkamos lygtys. Šio metodo analize rodo, kad ruožui virš takumo ribos aprašyti, t. y. kai $\varepsilon_{0,2} \leq \varepsilon_{S} \leq \varepsilon_{u}$, taikoma formule:

$$
\begin{gathered}
\sigma_{S 3}=\sigma_{0,2}+\left(\sigma_{u}-\sigma_{0,2}\right) \frac{k_{S 3} \eta_{S}-\eta_{S}^{2}}{1+\left(k_{S 3}-2\right) \eta_{S}} ; \\
\eta_{S}=\frac{\varepsilon_{S}-\varepsilon_{0,2}}{\varepsilon_{u}-\varepsilon_{0,2}} .
\end{gathered}
$$

Tempimo diagrama pirmame ruože išreiškiama tiese, antrame - parabole, trečiame - (8) lygtimi. Dydis $k_{S 3}$ randamas iš lygčiu sistemos, sudarytos iš kreivių ( 3 pav. a, ruožai $0-C$ ), einančių per mazginius taškus, ir bendros liestinès vienodo kreivumo sąlygos iš kairès ir dešinès nuo taško $\mathrm{B}$.

Reikia pašymèti, kad ir Euronormose [10-12] pateikiamas armatūros deformavimosi tempiant pobūdis yra panašus i 3 pav. pateikiamą. Tačiau $\sigma(\varepsilon)$ diagramos aprašymo analitinè išraiška nepateikiama, nors ji turi būti labai artima (7) lygčiai.

a)

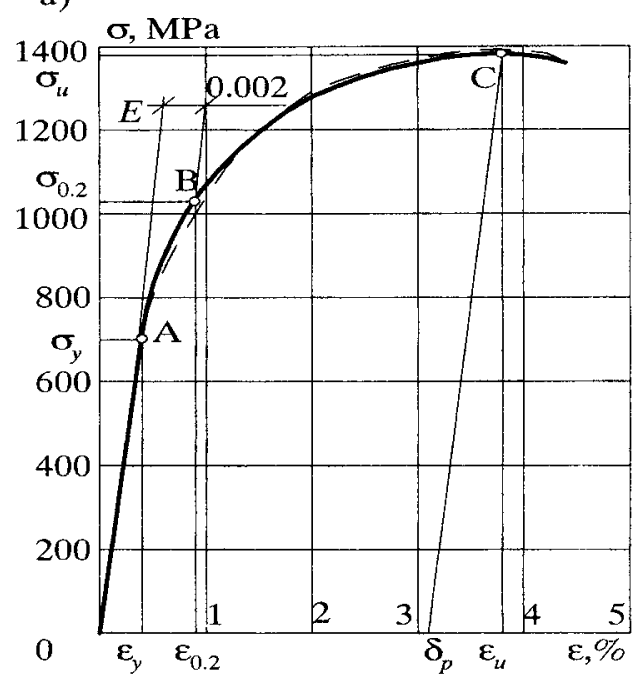

b)

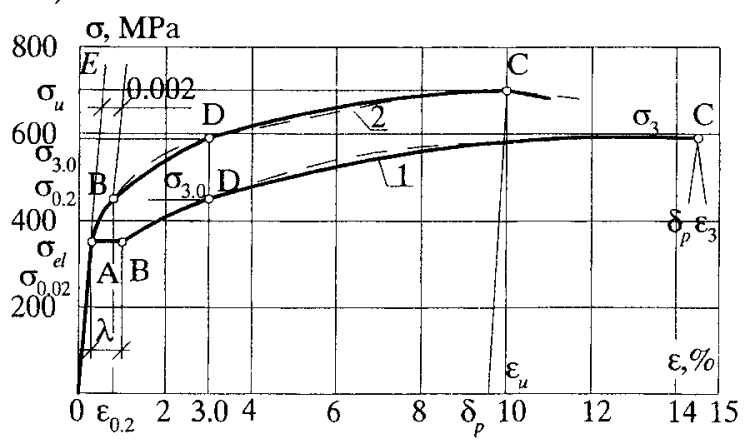

3 pav. Stipriosios (a) ir paprastos (b) armatūros deformavimosi diagramos: 1 - paprastos minkštosios armatūros, 2 - sustiprintos tempimu

Fig 3. Stress-strain curves for the high (a) and low (b) strength reinforcement: 1 - normal mild steel reinforcement, 2 - strengthened reinforcement 
Plienu su takumo aikštele diagramos taip pat dalijamos $\mathfrak{i}$ tris ruožus ( 3 pav. b), iš kurių du aprašomi pasviraja ir horizontaliaja tiesèmis, trečias - kreive pagal (7). Mazginiai taškai $0, A, B, C, D$ turi atitinkamas koordinates: 0,$0 ; \sigma_{e l}, \varepsilon_{e l_{1}} ; \sigma_{e l}, \varepsilon_{e l_{2}} ; \sigma_{3,0}, \varepsilon_{3,0} ; \sigma_{u}, \varepsilon_{u}$. Tarpinio mazgo $\mathrm{D}$ taikymas, rekomenduotas [6], leidžia lengvai nustatyti nežinomą dydi $k$ iš lygties, gautos kreivei einant per šį tašką 3-iame ruože:

$$
\sigma_{S 3}\left(\varepsilon_{3,0}\right)=\sigma_{3,0}
$$

$\sigma_{3,0}$ - itempiai, atitinkantys $\varepsilon_{3,0}=3 \%$ deformacijas.

Kiekviename ruože diagrama aprašoma lygtimis ivertinant tokias kraštines sąlygas:

$$
\begin{gathered}
0 \leq \varepsilon_{S} \leq \varepsilon_{e l_{1}}, \sigma_{S 1}=E_{S} \varepsilon_{S} ; \\
\varepsilon_{e l_{1}} \leq \varepsilon_{S} \leq \varepsilon_{e l_{2}}, \quad \sigma_{S 2}=\sigma_{e l} ; \\
\varepsilon_{e l_{2}} \leq \varepsilon_{S} \leq \varepsilon_{u}, \\
\sigma_{S 3}=\sigma_{e l}+\left(\sigma_{u}-\sigma_{e l}\right) \frac{k_{S 3} \eta_{S}-\eta_{S}^{2}}{1+\left(k_{S 3}-2\right) \eta_{S}} ; \\
\eta_{S}=\frac{\varepsilon_{S}-\varepsilon_{e l_{2}}}{\varepsilon_{u}-\varepsilon_{e l_{2}}} .
\end{gathered}
$$

Iš (10) lygties ir (12) formules nustatomas dydis:

$$
k_{S 3}=\frac{\left(\sigma_{u}-\sigma_{e l}\right) \eta_{3,0}-\left(\sigma_{3,0}-\sigma_{e l}\right)\left(2-\frac{1}{\eta_{3,0}}\right)}{\sigma_{u}-\sigma_{3,0}} .
$$

Tai rodo, kad pagal ši pasiūlymą armatüros deformavimąsi virš takumo ribos galima aprašyti (11) ir (12) lygtimis.

Yra pasiūlyta dèl paprastumo kreivuosius diagramos $\sigma_{s}\left(\varepsilon_{s}\right)$ ruožus tarp mazgu $0, \mathrm{~A}, \mathrm{~B}, \mathrm{C}$ pakeisti tiesemis ir siekiant didesnio tikslumo trečią ruožą rekomenduojama aproksimuoti dviem tiesèmis, taikant tarpini mazgą $D$. Taip gaunamos atkarpinès - tiesinès $\sigma_{s}\left(\varepsilon_{s}\right)$ diagramos, sudarytos iš 4 ruožų.

Analitinè $\sigma_{s}\left(\varepsilon_{s}\right)$ priklausomybès išraiška bendruoju atveju užrašoma taip:

$$
\sigma_{S}=\sigma_{S 0}+\bar{E}_{S}\left(\varepsilon_{S}-\varepsilon_{S 0}\right)
$$

čia $\bar{E}_{S}=\frac{\sigma_{S R}-\sigma_{S 0}}{\varepsilon_{S R}-\varepsilon_{S 0}}-$ atskiro ruožo tiesès posvyrio kampas. Akivaizdu, kad pirmame ruože diagramos $\bar{E}_{S}$ reikšmė sutampa su plieno tamprumo moduliu $E_{S}$. Ruožų galai aprašomi tomis pačiomis koordinatemis, kaip ir kreivujų diagramų ruožai, ivvertinant papildomą tašką $\mathrm{D}$.

Praktiniam skaičiavimui tiesinę $\sigma_{s}\left(\varepsilon_{s}\right)$ priklausomybę virš takumo ribos siūloma taikyti ir Euronormose [10-12]. Šios diagramos tiesios dalies (4 pav.) posvyrio kampas $\beta$ priklauso nuo armatūros savybių. Laikoma, kad didžiausias pailgèjimas iki $\sigma_{\max } \varepsilon_{s}=\varepsilon_{u} \leq 10 \%$. Labai plastiškai armatūrai, kai $\varepsilon_{u}>5 \%, \sigma_{u} / \sigma_{y}=1,08$ ir kai $\varepsilon_{u}>2,5 \%, \sigma_{u} / \sigma_{y}=1,05$. Visais atvejais laikoma, $\mathrm{kad}$ $E_{s}=200 \mathrm{kN} / \mathrm{mm}^{2}$. Vadinasi, galima laikyti, kad posvyrio kampas $\beta$ yra:

$$
\beta=\operatorname{tg} \frac{\sigma_{u}-\sigma_{y}}{\varepsilon_{u}-\frac{\sigma_{u}}{E_{s}}} .
$$

Tai leidžia nesunkiai apskaičiuoti armatūros deformacijas virš takumo ribos. Tačiau yra irodyta [13], kad skaiciuojant gelžbetoninių konstrukciju deformacijas, medžiagu $\sigma(\varepsilon)$ diagramos forma turi didelę itaką rezultatų tikslumui. Todèl kreivosios diagramos analitinis aprašymas turi didelę reikšmę tikslesniam mišriai armuotų gelžbetoninių konstrukcijų būvio po apkrova aprašymui.

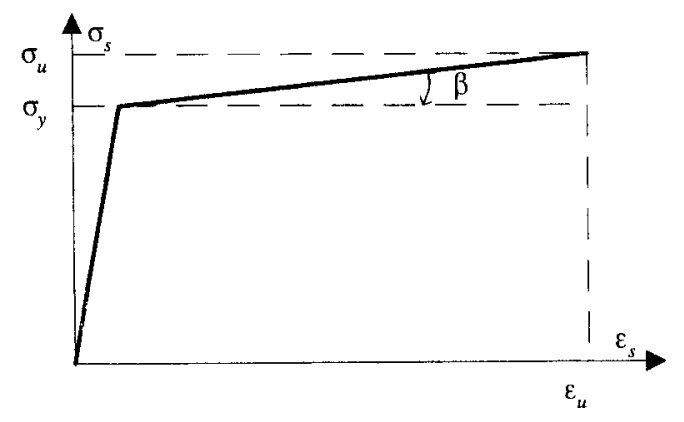

4 pav. Itempių-deformacijų priklausomybè pagal Euronormas (15)

Fig 4. Stress-strain curve by Eurocode formula (15)

Mūsų atlikta $\sigma(\varepsilon)$ priklausomybių analizè rodo jų ivairovę, vertinant kai kurias armatūros savybių charakteristikas.

5 pav. pateiktı $\sigma(\varepsilon)$ priklausomybiu grafiku, gautu pagal ịvairiu autoriu pasiūlytas formules ((2), (4), (5), (7), (15)), analizè rodo skirtingus rezultatus, palyginti su eksperimentiniais duomenimis.

\section{Ivairių klasių armatūrų deformavimosi apibendrin- tas analitinis aprašymas}

Kaip rodo atlikta analizè, nèra nusistcvejusios metodikos ir analitinès išraiškos aprašyti tampriai plastinius 
armatūros ịtempius-deformacijas. Daugumai šių būdų yra artima arba toliau tobulinama tokia lygtis [7]:

$$
\varepsilon_{s}=\frac{\sigma_{s}}{E_{s}}+C\left(\frac{\sigma_{s}}{\sigma_{0,2}}-\eta_{s}\right)^{n}
$$

Ji rekomenduojama plienams, kurių $\sigma_{u} / \sigma_{0,2} \approx$ $\approx 1,05 \div 1,17$. Reikia pažymèti, kad šios ribos daugeliu atvejų atitinka tarptautinių ständartų reikalavimus [10-12].

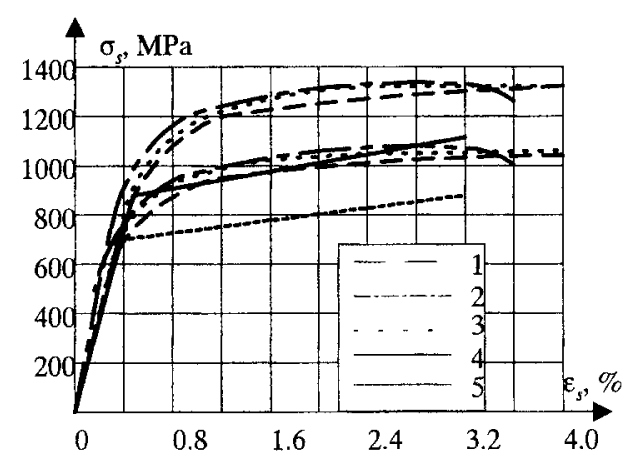

5 pav. Teoriniu priklausomybių palyginimo analize armatūrai $\mathrm{A}_{\mathrm{T}} \mathrm{VI}$ ir $\mathrm{A}_{\mathrm{T}} \mathrm{V} ; 1$ - pagal $(2,4)$ formules; 2 - pagal $(5) ; 3$ - pagal (7); 4 - pagal Euronormas (15) $A_{T}$ VI armatūrai; 5 - pagal Euronormas (15) $\mathrm{A}_{\mathrm{T}} \mathrm{V}$ armatūrai

Fig 5. Agreement of theoretical stress-strain curves of $A_{T}$ VI and $A_{T} V$ reinforcement; 1 - by formulas $(2 ; 4) ; 2$ - by formula (5); 3 - by formula (7); 4 - by Eurocode formula (15) for $A_{T} V I$ reinforcement; 5 - by Eurocode formula (15) for $A_{T} V$ reinforcement

Mūsų atlikta analizè taip pat rodo, kad (16) priklausomybè gali būti taikoma ivvairių klasių armatūros deformavimuisi aprašyti. Ją palyginus su eksperimentiniais duomenimis [14], matyti, kad koeficientas $\eta_{s}$ lygus santykiui $\sigma_{0,2} / \sigma_{u}$. Koeficiento $n$ reikšmę reikia imti atsižvelgiant $\mathfrak{i} \sigma_{0,2} / \sigma_{u}$ santykị, o koeficiento $C$ reikšmę priklausomai nuo plieno klasès.

$C, \eta_{s}$ ir $n$ koeficientai buvo taikomi jvertinant armatūros klasių savybes ir atsižvelgiant ị mūsų ir [7] pateiktus eksperimentinius duomenis. Be to, sąlyginès takumo ribos viršijimui nustatyti, atsižvelgiant i (16) išraišska, siüloma tokia formulè:

$$
\varepsilon_{s}=C\left(\frac{\sigma_{s}}{\sigma_{0,2}}-\eta_{s}\right)^{n_{1}}
$$

Atlikta eksperimentinių duomenų analizè ir teoriniai skaičiavimai parodè, $\operatorname{kad} C, \eta_{s}$ ir $n_{1}$ koeficientų reikšmès priklauso nuo armatūros klasès (1 lent.).

6 pav. pateikti duomenys rodo, kad mūsų pasiūlytos tampriai plastiniu armatūros deformacijų skaičiavimo metodikos rezultatai geriau sutampa su eksperimentiniais duomenimis nei skaičiavimas pagal (16).

1 lentelè. Koeficientai $C, \eta_{s}$ ir $n_{1}$

Table 1. Coefficients $C, \eta_{s}$ and $n_{1}$

\begin{tabular}{|c|c|c|c|}
\hline $\begin{array}{c}\text { Armatūros } \\
\text { klasè }\end{array}$ & $C$ & $\eta_{s}$ & $n_{1}$ \\
\hline $\mathrm{A}_{\mathrm{T}} \mathrm{IV}$ & 0,069 & 0,70 & \\
$\mathrm{~A}$ IV & 0,079 & 0,70 & $\sigma_{0,2}$ \\
$\mathrm{~A}_{\mathrm{T}} \mathrm{V}$ & 0,092 & 0,75 & $\sigma_{s}$ \\
$\mathrm{~A} \mathrm{~V}$ & 0,100 & 0,75 & \\
$\mathrm{~A}_{\mathrm{T}} \mathrm{VI}$ & 0,115 & 0,80 & \\
\hline
\end{tabular}

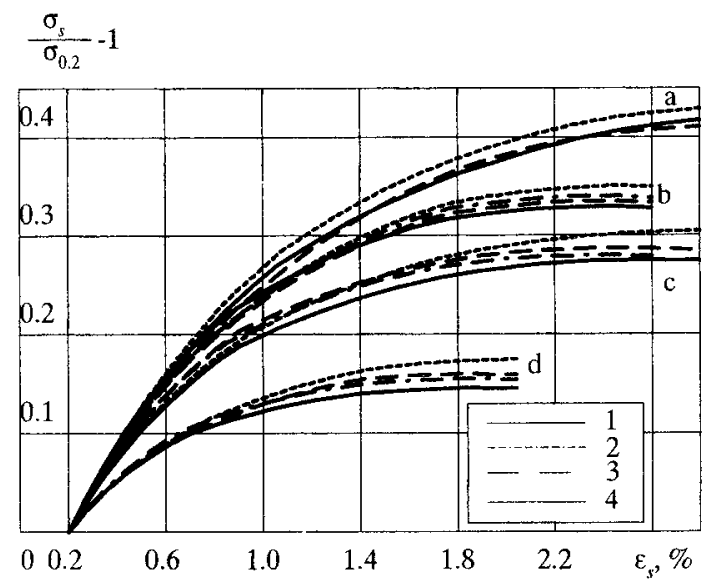

6 pav. Eksperimentinių ir teoriniu kreiviu palyginimas: a - armatüra $A_{T} I V ; b-A ~ V ; c-A_{T} V ; d-A_{T} V I ; 1$ - eksperimentiniai pagal [7]; 2 - eksperimentiniai pagal [14]; 3 - teoriniai pagal (17) formulę; 4 - teoriniai pagal (16) formulę

Fig 6. Agreement of experimental and theoretical stress-strain curves for $A_{T} I V$ reinforcement (a); $A V$ reinforcement (b); $A_{T}$ $\mathrm{V}$ reinforcement (c); $A_{T} V I$ reinforcement (d); 1 - experimental by [7]; 2 - experimental by [14]; 3 - theoretical by formula (17); 4 - theoretical by formula (16)

Kadangi tikslus analitinis armatūros $\sigma(\varepsilon)$ kreives priklausomybès aprašymas praktiškai neimanomas, reikia ivertinti šios kreivès paklaidas. Kaip deformacijų skaičiavimo pagrindas imta tokia priklausomybè:

$$
\varepsilon_{s}=\frac{\sigma_{s}}{E_{s}}+C\left(\frac{\sigma_{s}}{\sigma_{0,2}}-\eta_{s}\right)^{n \frac{\sigma_{0,2}}{\sigma_{s}}}
$$

6 pav. kreivių analizè rodo, kad skaičiavimo rezultatai ne tik gerai sutampa su eksperimentais, bet ir yra nepertraukiama funkcija. Kaip buvo pateikta, taip pat pagal [7], veiksniai, nulemiantys priklausomybès $\sigma(\varepsilon)$ tiksluma, yra koeficientai $C, \eta_{s}$ ir $n$ (18 formule) . Norint ivertinti šiu veiksnių itaką $\sigma(\varepsilon)$ diagramų formai, buvo imtos ivairios jų reikšmès ( 2 lent.). 
2 lentelè. Koeficientu $C, \eta_{s}$ ir $n_{1}$ reikšmès

Table 2. Values of coefficients $C, \eta_{s}$ and $n_{1}$

\begin{tabular}{|c|c|c|c|}
\hline $\begin{array}{c}\text { Armatūros } \\
\text { klasè }\end{array}$ & $C$ & $\eta_{s}$ & $n_{1}$ \\
\hline A IV & 0,$049 ; 0,059$ & 0,$65 ; 0,70 ; 0,75$ & \\
& 0,$069 ; 0,079$ & & \\
& 0,089 & 0,$65 ; 0,70$ & \\
$\mathrm{~A}_{\mathrm{T}}$ IV & 0,$079 ; 0,089$ & 0,75 & \\
& 0,$099 ; 0,109$ & & $3 ; 3,5$ \\
& 0,119 & 0,$70 ; 0,75$ & $4 ; 4,5$ \\
A V & 0,$092 ; 0,102$ & 0,80 & \\
& 0,$112 ; 0,122$ & & \\
& 0,132 & 0,$70 ; 0,75$ & \\
$\mathrm{~A}_{\mathrm{T}} \mathrm{V}$ & 0,$100 ; 0,110$ & 0,80 & \\
& 0,$120 ; 0,130$ & & \\
& 0,140 & 0,$75 ; 0,80$ & \\
$\mathrm{~A}_{\mathrm{T}} \mathrm{VI}$ & 0,$750 ; 0,085$ & 0,85 & \\
& 0,$095 ; 0,105$ & & \\
& 0,115 & & \\
\hline
\end{tabular}

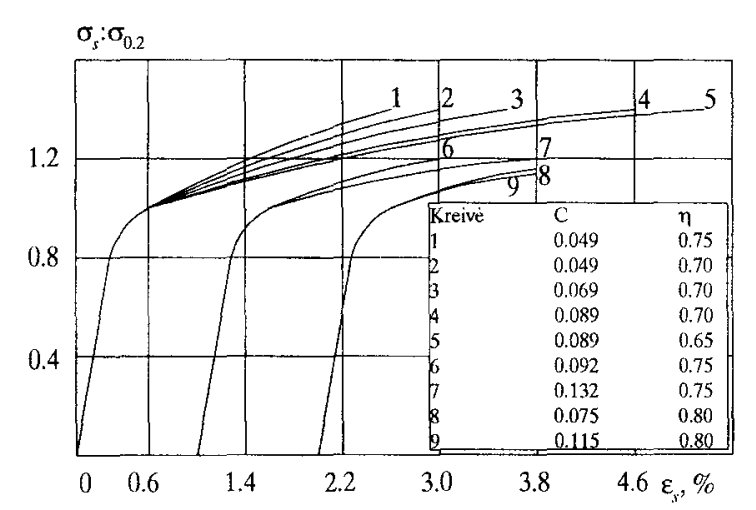

7 pav. Armatūros diagramos formos priklausomybè nuo koeficientų $C, \eta_{s}$ ir $n$

Fig 7. Influence of different values of the coefficients $C, \eta_{s}$ and $n$ on the form of stress-strain curves of reinforcement

7 pav. pateikta diagrama rodo, kad priklausomai nuo armatūros savybių $\sigma(\varepsilon)$ diagramos virš takumo ribų diapazonas gana platus.

Armatūrinių plienų su aiškiai išreikšta takumo aikštele $\sigma(\varepsilon)$ diagramos analitiniam skaičiavimui pateikiamos apibendrintos metodikos [8,9]. Itempių-deformacijų kreivès išreiškiamos ne sklandžia kreive, kuri būtų aprašoma viena lygtimi, bet dalijamos ị ruožus. Aprašant viena lygtimi prarandamas tikslumas takumo aikštelès ruože. Mūsu atlikti bandymai su šia armatūra leidžia pateikti išraiška, kuri pakankamai tikslai rodo minkštujų plienų deformavimosi pobūdị. Gauta tokia analitinè priklausomybė:

$$
\varepsilon_{s}=\left\{\begin{array}{l}
\frac{\sigma_{s}}{E_{s}}, 0 \leq \sigma_{s} \leq \sigma_{e l, 1} \\
\frac{\sigma_{s}}{E_{s}}, \sigma_{e l 1} \leq \sigma_{s} \leq \sigma_{e l 2} \\
\sqrt{\frac{D+G \sigma_{s}}{1+F \sigma_{s}}}, \sigma_{e l 2} \leq \sigma_{s} \leq \sigma_{u}
\end{array},\right.
$$

$D, F, G$ - koeficientai, priklausantys nuo armatūros klasès.

Kiekvienos klasès armatūrai koeficientai yra skirtingi. Pavyzdžiui, A III klasès armatūriniam plienui $D=-0,87 \cdot 10^{-3}$; $F=-1,37 \cdot 10^{-3} ; G=0,0014 \cdot 10^{-3}$. Tarptautiniame standarte ISO 10080 armatūrai B500A šie koeficientai lygūs atitinkamai: $D=-0,85 \cdot 10^{-3} ; F=-1,58 \cdot 10^{-3} ; G=0,00167 \cdot 10^{-3}$.

Gauta eksperimentinè kreivè ir teorinių priklausomybių grafinè išraiška pateikti 8 pav.

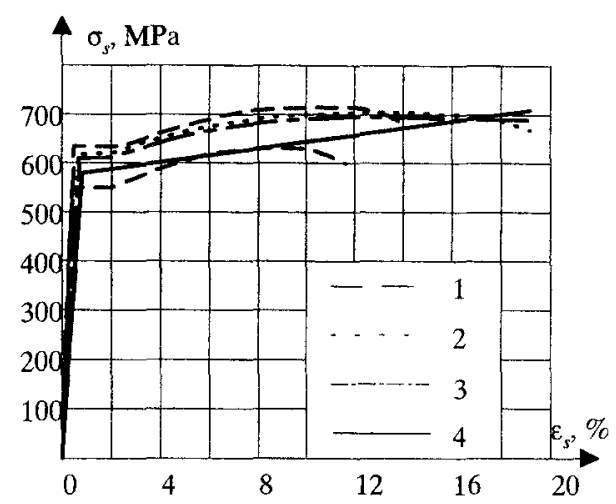

8 pav. Minkštojo plieno deformavimosi schemos: 1 - eksperimentiniai pagal $[15,16] ; 2$ - autorių eksperimentai; 3 - teoriné pagal (19) formulę; 4 - teorinè pagal Euronormas (15)

Fig 8. Stress-strain curves for mild steel reinforcement: 1 experimental by $[15,16] ; 2$ - experimental developed by authors of the present paper; 3 - theoretical by formula (19); 4 - theoretical by Eurocode formula (15)

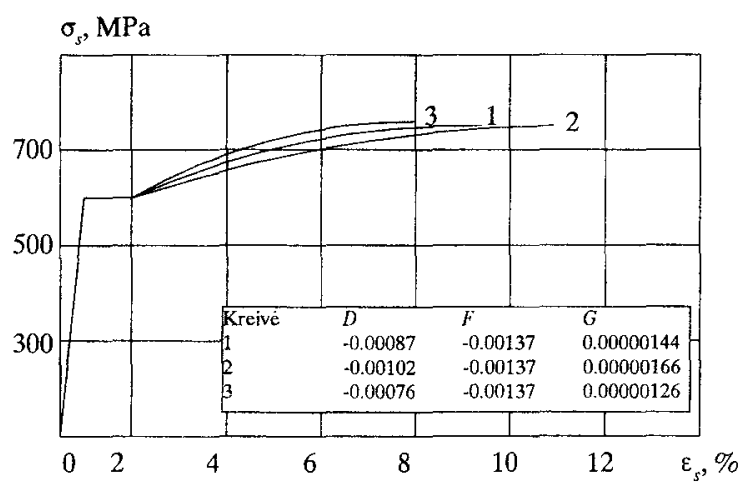

9 pav. Armatūros diagramos formos priklausomybè nuo koeficientų $D, F$ ir $G$

Fig 9. Influence of different values of the coefficients $C, \eta_{s}$ and $n$ on the form of stress-strain curves of reinforcement 
Palyginus šiuos duomenis matyti, kad eksperimentiniai ir teoriniai rezultatai, apskaičiuoti pagal siūlomą (19) priklausomybę, gerai sutampa. Šie tyrimai taip pat rodo, kad taikant Euronormose siūlomą metodiką minkštiesiems plienams ne visada gaunami pakankamai geri rezultatai. Joje neịvertinama krintančioji kreivès dalis, kas ypač svarbu analizuojant konstrukcijų būvị irimo stadijoje arba nustatant iražų persiskirstymą.

Iš 9 pav. pateiktos diagramos matyti, kad priklausomai nuo armatūros savybių $\sigma(\varepsilon)$ diagramos virš takumo ribų diapazonas yra gana platus.

\section{Išvados}

1. Analizuojant gelžbetoninių konstrukcijų deformavimąsi ịvairiose stadijose, iskaitant irimo stadija, nustatant irąžų persiskirstymą tarp ivvairiai įtemptų armatūru yra būtina žinoti tikslias tempiamosios armatüros deformavimosi $\sigma(\varepsilon)$ priklausomybes.

2. Armatūros $\sigma(\varepsilon)$ diagramoms aprašyti taikoma daug ivairių priklausomybių. Jų analizè parodé, kad, skaičiuojant gelžbetonines konstrukcijas, medžiagu $\sigma(\varepsilon)$ diagramos forma ir aprašymas turi didelę itaką rezultatų tikslumui. Ypač didelę reikšmę turi diagramos dalies virš takumo ribos forma.

3. Ivairių autorių pasiūlytos priklausomybès skirtingai sutampa su eksperimentiniais rezultatais, skiriasi savo sudètingumu ir praktinio taikymo galimybemis.

4. Atlikus teorinius bei eksperimentinius tyrimus ir juos palyginus su kitu autoriu darbais, pasirodè, kad geriausi rezultatai priklausomybei virš takumo aprašyti gaunami taikant (17) ir (19) formules.

5. Pasiūlytos lygtys ir jų koeficientai tinka ivairių klasių, taip pat ir tarptautiniame standarte ISO-100 80 reglamentuojamu savybių armatūru $\sigma(\varepsilon)$ priklausomybèms virš takumo ribos aprašyti.

\section{Literatūra}

1. A. Šneideris. Stiprinamų lenkiamų gelžbetoninių konstrukciju pradinio ịtempimų-deformacijų būvio teorinio ivertinimo prielaidos // Pirmosios respublikines jaunujų mokslininku konferencijos „Lietuva be mokslo - Lietuva be ateities“, ivykusios Vilniuje $19980930-1002$, medžiaga. 1 t. V.: Technika, 1998, p. 165-171.

2. G. Marčiukaitis, A. Šneideris. Eksploatuojamų lenkiamų gelžbetoninių konstrukcijụ įtempių-deformaciju būvio ivertinimo metodu parinkimo klausimu // Statybinès konstrukcijos: kūrimas ir stiprinimas. Konferencijos, ivykusios Vilniuje $1998 \mathrm{~m}$. lapkričio $20 \mathrm{~d}$., pranešimu medžiaga. V.: Technika, 1998, p. 43-47.
3. Z. Kamaitis, V. Jokūbaitis. Gelžbetoninių ir mūrinių konstrukcijų atstatymas ir stiprinimas. Mokomoji knygelè. Vilnius: Technika, $1986.92 \mathrm{p}$.

4. Д. Н. Лазовский. Теория расчета и конструирование железобетонных конструкций эксплуатируемых строительных сооружений // Автореферат дис. ... д-ра техн. наук. Минск, 1998. $41 \mathrm{c}$.

5. Б. А. Макеров, Л. Р. Маилян. Аналитическое описание диаграммы растяжения высокопрочной арматурной стали // Новые виды арматуры и ее сварка. Всесоюзное совещание. Тезисы докладов. Волгоград, сентябрь 1982. М.: Госстрой СССР, НИИЖБ, 1982, с. 166-171.

6. В. Н. Байков, С. А. Мадатян, Л. С. Дудоладов, В. М. Митасов. Об уточнении аналитических зависимостей диаграммы растяжения арматурных сталей // Нзв. вузов. Строительство и архитектура, 1983, № 9, с. 1-5.

7. Н. М. Мулин. Стержневая арматура железобетонных конструкций. М.: Стройиздат, 1975. 233 с

8. Кодекс-образец ЕКБ-ФИП для норм по железобегонным конструкциям. М.: Стройиздат, 1984.

9. ENV 10080: 1995 D. European Committee for standartization. Steel for the Reinforcement of concrete weldable ribbed reinforcing steel B 500. Technical delivery conditions for bars, coils and welded fabric. Bruxelles, $1995.80 \mathrm{c}$.

10. British Standards Institution. Eurocode2: Design of Concrete Structures - Part I. General Rules and rules of Buildings, London, 1992. DD ENV 1922-1-1: 1992. 364 c.

11. Concrete Structures Euro-Design Handbook. Edit. by Eibl J., Berlin, Erkstand Sohn, 1995. 754 p.

12. Л. Р. Маилян. Сопротивление железобетонных статически неопределимых балок силовым воздейсгвиям. Ростов-на-Дону: Издательство Ростовского университета, $1989.176 \mathrm{c}$.

13. Г. В. Марчюкайтис. Влияние формы полных диаграмм $\sigma(\varepsilon)$ материалов на прочность и кривизну изгибаемых армированных бетонополимерных материалов // Тезисы докладов республиканской конференции "Физикомеханические свойства бетонов с полимерами". Вильньос, 1978 , с. $40-43$.

14. Г. В. Марчюкайтис. Исследование физико-механических свойств бетона и железобетона, пропитанных полимерами, и учет их особенностей при расчете конструкций: Дис. ... д-ра техн. н. Вильнюс - Москва, $1979.407 \mathrm{c}$.

15. С. А. Мадатян. Общие тенденции производства и применения обычной и напрягаемой арматуры // Бетон и железобетон, 1997, № 1, с. 2-5.

16. С. А. Мадатян. Новое поколение арматуры железобетонных конструкций // Бетон и железобетон, 1998, № 2, c. 2-5.

Iteikta 19990920

\section{DETERMINATION OF RELATIONSHIP $\sigma(\varepsilon)$ OVER THE YIELD STRESS OF CONCRETE REINFORCING STEELS}

\section{G. Marčiukaitis, A. Šneideris}

\section{Summary}

Calculating and designing the tension zone of strengthening concrete structures and analysing its workability in stages which are close to break-up stage and distribution internal forces, existing various reinforcements, it is necessary to know 
characteristics of deformation and their change. Experiments show that forms of relationship between stress and strain of concrete reinforcing steels have great influence on accuracy of determination of reinforced concrete structures during all work stages of these structures. There are various analytic expressions for describing relationship of stress-strain and deformation of reinforcement. Our analysis showed that results of calculation for the same type of reinforcement are different. Methods suggested by Eurocode 2 also do not give accurate analytic expression of $\sigma(\varepsilon)$ diagrams part over yield limit.

The analysis and comparison of offered analytic $\sigma(\varepsilon)$ expressions showed that the basis of a more accurate description of this relationship may be the accepted formula (16). Its application for description of $\sigma(\varepsilon)$ relationship of different classes of reinforcing steel is suggested. Formula (17) is suggested for description of $\sigma(\varepsilon)$ over yield point. Equation (19) is suggested for description of mild steels and deformation of reinforcement over yield limit by standard ISO - 10080 .
Gediminas MARČIUKAITIS. Professor, Doctor Habil. Head of Dept of Reinforced Concrete and Masonry Structures. Vilnius Gediminas Technical University (VGTU), Sauletekio al 11, LT-2040 Vilnius, Lithuania.

A graduate of Civil Engineering Faculty of Kaunas Polytechnic Institute (1957). $\mathrm{PhD}$ (1963). Research visit to the University of Illinois (1969). Doctor Habil (1980, Moscow Civil Engineering Institute). Professor since 1982. Author and coauthor of 5 monographs, 4 text-books and about 300 scientific articles. Research interests: mechanics of reinforced concrete, masonry and layered structures, new composite materials, structures and investigation and renovation of buildings.

Arnoldas ŠNEIDERIS. MSc (Eng). Vilnius Gediminas Technical University (VGTU), Sauletekio al. 11, LT-2040 Vilnius, Lithuania.

A graduate of Vilnius Technical University (1993, civil engineer). MSc (1995). Doctoral student (Dept of Reinforced Concrete and Masonry Structures, VGTU). Research interests: mechanics of reinforced concrete, strengthening of structures. 